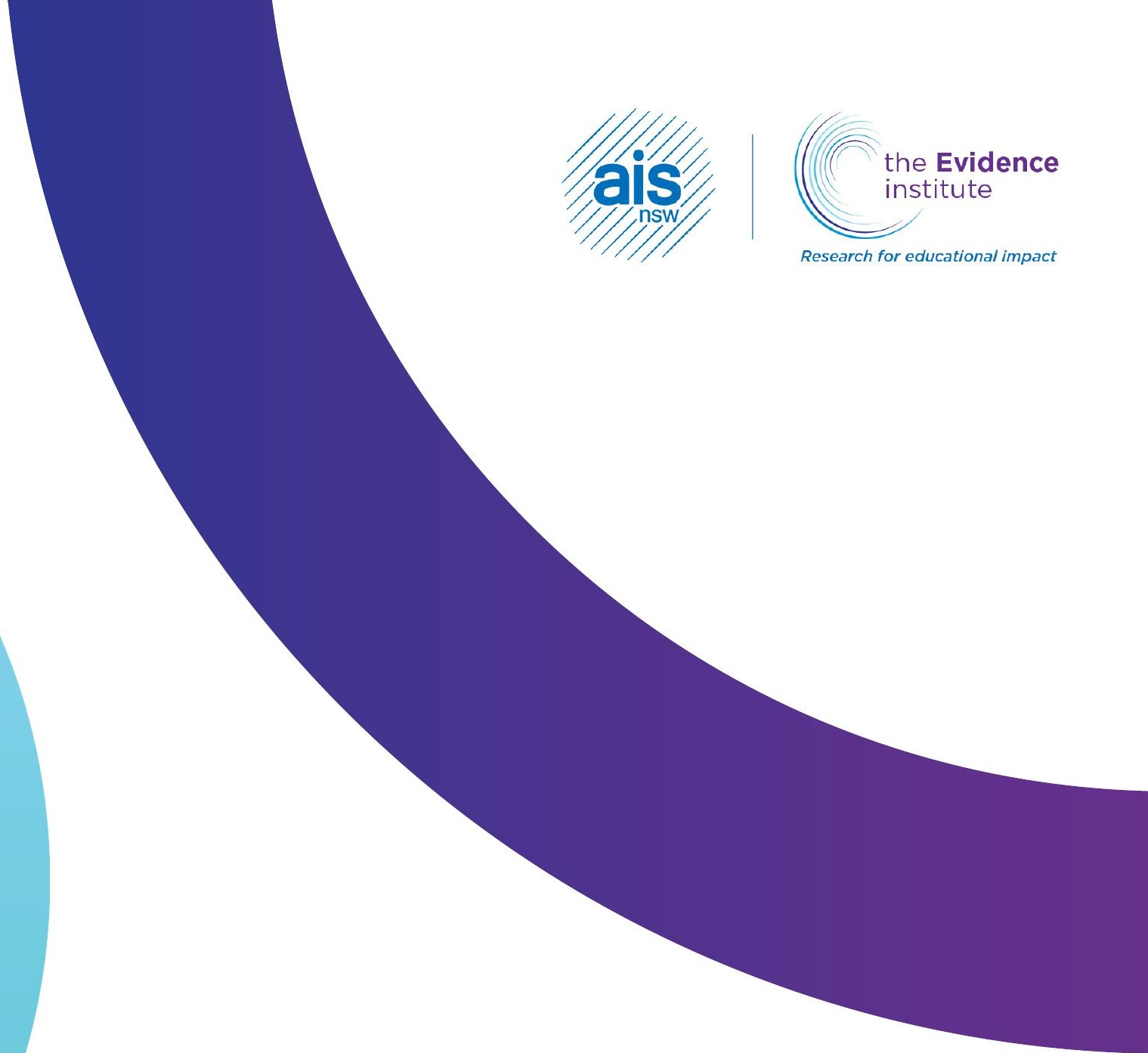

\title{
REMOTE LEARNING
}

Rapid

Literature Review

September 2020 
Australian Council for Educational Research (ACER)

19 Prospect Hill Road

Camberwell VIC 3124

Phone: +61 392775555

ABN 19004398145

www.acer.org

ISBN 978-1-74286-610-9

(C)2020 The Association of Independent Schools of NSW

Level 12, 99 York Street, Sydney NSW 2000

Phone +61 292992845

ABN 96003509073

www.aisnsw.edu.au

\section{(c) (i) (8)}

With the exception of any material protected by a trademark, and where otherwise noted, all material presented in this document is provided under a Creative Commons Attribution NonCommercial 4.0 International Licence http://creativecommons.org/licenses/by-nc/4.0

\section{Citation}

Cowden, G., Mitchell. P., \& Taylor-Guy, P. (2020). Remote learning. Rapid Literature Review. Association of Independent Schools NSW \& Australian Council for Educational Research. https://doi.org/10.37517/978-1-74286-610-9 


\section{CONTENTS}

1. EXECUTIVE SUMMARY

2. INTRODUCTION

2.1 Definitions

3. EDUCATION IN EMERGENCIES

3.1 Emergency education - research

3.1.1 Crisis leadership

3.2 Implications for wellbeing

3.2.1 Student wellbeing

3.2.2 Teacher wellbeing

4. QUALITY TEACHING AND LEARNING

4. 1 Learning design

4.1.1 Distance education research

4.1.2 Blended learning research

4.1.3 Online learning research

5. THE ROLE OF TECHNOLOGY

5.1 Teacher and student readiness and capability

5.2 Access

6. CONTEXT IS IMPORTANT

6.1 Differentiation

7. THE HOME LEARNING ENVIRONMENT

7.1 The role of parents and caregivers

7.2 Implications for learning from home

7.3 Social and educational vulnerability

7.4 Resources to enable remote learning

7.4.1 Books

7.4.2 Online resources

8. CONCLUSION

Definitions

References

Appendix A Pedagogical models for remote learning

Mobile learning framework

Online learning framework

Online engagement matrix 


\section{EXECUTIVE SUMMARY}

The COVID-19 pandemic is the first global crisis in the digital-age.

The extraordinary and unprecedented circumstances of school closures due to the COVID-19 pandemic have resulted in an unexpected shift to remote learning, with many teachers and students having to rapidly adopt educational tools and methods with little or no training (Thomson, 2020).

In Australia, the continuing pandemic has brought into sharp focus long-standing issues of access and equity, and teacher and student preparedness for learning using technology. It has however, highlighted opportunities for these challenges to be better addressed, for students and teachers to learn and teach differently, more inclusively, more creatively, and to consider what the future of education in Australia might become.

This review highlights four key themes:

1. Quality of teaching matters. Teachers need the skills and knowledge to design learning that can transfer across learning environments, including online and blended. They require support to maintain the principles of good pedagogical practice that hold true regardless of the mode of delivery.

2. The role of technology. Learning needs and purpose, not technology, should shape schools' responses to remote learning. Considered use of technology can aid, but not replace, good teaching. School and class-specific resources that have been developed by teachers who know their learners, are always going to be superior to off-the-shelf, generic educational technology solutions.

3. Context is important. No one size fits all. School leaders and teachers who know their communities and students are best placed to select an appropriate and targeted response to learning design. The age of children, and access to resources for learning, are drivers of differentiated responses.

4. The home learning environment. Access to resources in the home and supporting the role of parents/caregivers is particularly important during periods of remote learning. Schools can play a key role in providing a range of learning materials and practical strategies for families.

These key themes underpin all good pedagogical practice regardless of mode of delivery or context. 


\section{INTRODUCTION}

This rapid literature review identifies effective practice in remote learning and synthesises key evidence relevant to education in Australia during the 2020 COVID-19 pandemic. It draws upon bodies of literature about education in emergencies, access and equity, distance education, blended learning, and quality teaching and learning using technology. The focus is primarily on Kindergarten to Year 12 schooling in Australia.

Although large-scale remote learning has never been experienced before, it is possible to identify effective practice by using robust studies from non-pandemic-related literature. These insights can be considered in light of emergent literature, commentary in academic media and in journals, and information published on educational, government, and professional websites.

The literature firstly examines education in emergencies, as this underpins the initial crisis approaches and preparedness for the shift to remote learning. The research in this area has a strong focus on implications for wellbeing. The review is then organised into sections that align with the four key themes identified in the literature:

- Quality teaching and learning

- Technology in education

- Context is important

- The home learning environment.

Pedagogical models and frameworks examined in the literature are presented and discussed in Appendix A.

The structure of this review assists in providing clearer navigation of the complex learning contexts experienced by schools and families during this pandemic. Through this lens, schools and education sectors can reflect upon their response, how they might be best prepared for ongoing and future situations, and how schooling might be improved.

\subsection{Definitions}

A wide body of literature from the past two decades has guided the way that learning is discussed across school and non-school settings. This is with or without the use of technology.

Emergency remote teaching (ERT) is the definition best used to describe the approach to remote teaching and learning during the pandemic. It is a "temporary shift of instructional delivery" due to crisis circumstances (Hodges et al., 2020, n.p.). The differences between emergency remote teaching and well-planned online learning are discussed by Hodges et al., (2020), who make the important point that emergency remote teaching is a rapid approach that is unable to make full use of quality online learning design approaches (Hodges et al., 2020).

Other definitions used in this review are located after the conclusion. 


\section{EDUCATION IN EMERGENCIES}

Most pre-pandemic literature around education in emergencies (EiE) relates to fragile states and natural disasters. EiE literature is relevant to this review as it offers good practice principles for re-establishing and continuing education following a crisis, and offers understandings of crises responses from different perspectives. Literature specific to the wellbeing of school students in the COVID-19 crisis is emerging.

\subsection{Emergency education - research}

Emergency education literature relating to crisis situations stresses the importance of education programs that support children's wellbeing, and focus on children's rights to protection and to education (1948 Universal Declaration of Human Rights; 1989 Convention of the Rights of the Child; 1990 World Declaration on Education for All; Sustainable Development Goal 4).

Successful crisis response involves a series of phases. Preparedness, the response itself, and recovery are the three stages used by the Inter-agency Network for Education in Emergencies (INEE, 2020). The literature and toolkits provided by INEE (Nicolai, 2003), provide evidence of practical relevance for the Australian context. The success and durability of responses is dependent upon:

- $\quad$ Cultural (contextual) appropriateness

- Mobilising partnerships with agencies, communities and families

- Making available flexible resources based on the existing curriculum that can support continuity of teaching and learning for all students

- Ensuring that leaders, educators, students, families and communities have the appropriate knowledge and skills to ensure educational continuity in an emergency.

Recognising that phases are unlikely to be linear, the response phase involves establishing a safe, supervised environment in which students engage in structured activities and daily routines that "help students regain a sense of normality and ease parents' concerns" (Nicolai, 2003, p.32).

Partnering with community and authorities is a common theme in current and historic literature. A study of schools (in the US) during the 1918 pandemic identified that a successful response occurs when "planning brings public health, education officials, and political leaders together" (Battenfeld, 2020, n.p.), and the smooth implementation of policies in the 1918 pandemic "was associated with clear lines of authority among agencies" (Stern et al., 2009, p.1066). As part of the review of responses to the 1918 pandemic, Stern et al., (2009) also found "the smooth implementation of school closure was consistently associated both with a clear delineation of authority among municipal and governmental agencies and with existing trust and transparent communication between health officials and the population at large" (p.1067).

Similarly, research relating to the effect of bushfires in Australia on schooling found that "the leadership team must adapt, work and innovate with the teachers and staff, parents, the broader community, the assets management teams and other schools" (Nye, 2016, p. 94). This holds true in the current pandemic where the capacities of the whole community are impacted. Of note is that strengthened school-community-parental relationships were commonly mentioned in the disaster experience literature (Nye, 2016; O'Connor \& Takahashi, 2014). 


\subsubsection{Crisis leadership}

There is a myriad of literature on crisis leadership theory, however, less common is literature discussing operational expectations during response and recovery stages. School leadership in times of crisis requires a distinctive set of competencies and skills (Mutch, 2015; Smith \& Riley, 2012). As shown in Figure 1, this includes decisive decisionmaking, intuition and flexibility, creativity and lateral thinking, tenacity and optimism, procedural, intuitive, and creative intelligence, different ways of thinking, and communication and media skills (Smith \& Riley, 2012, p.65).

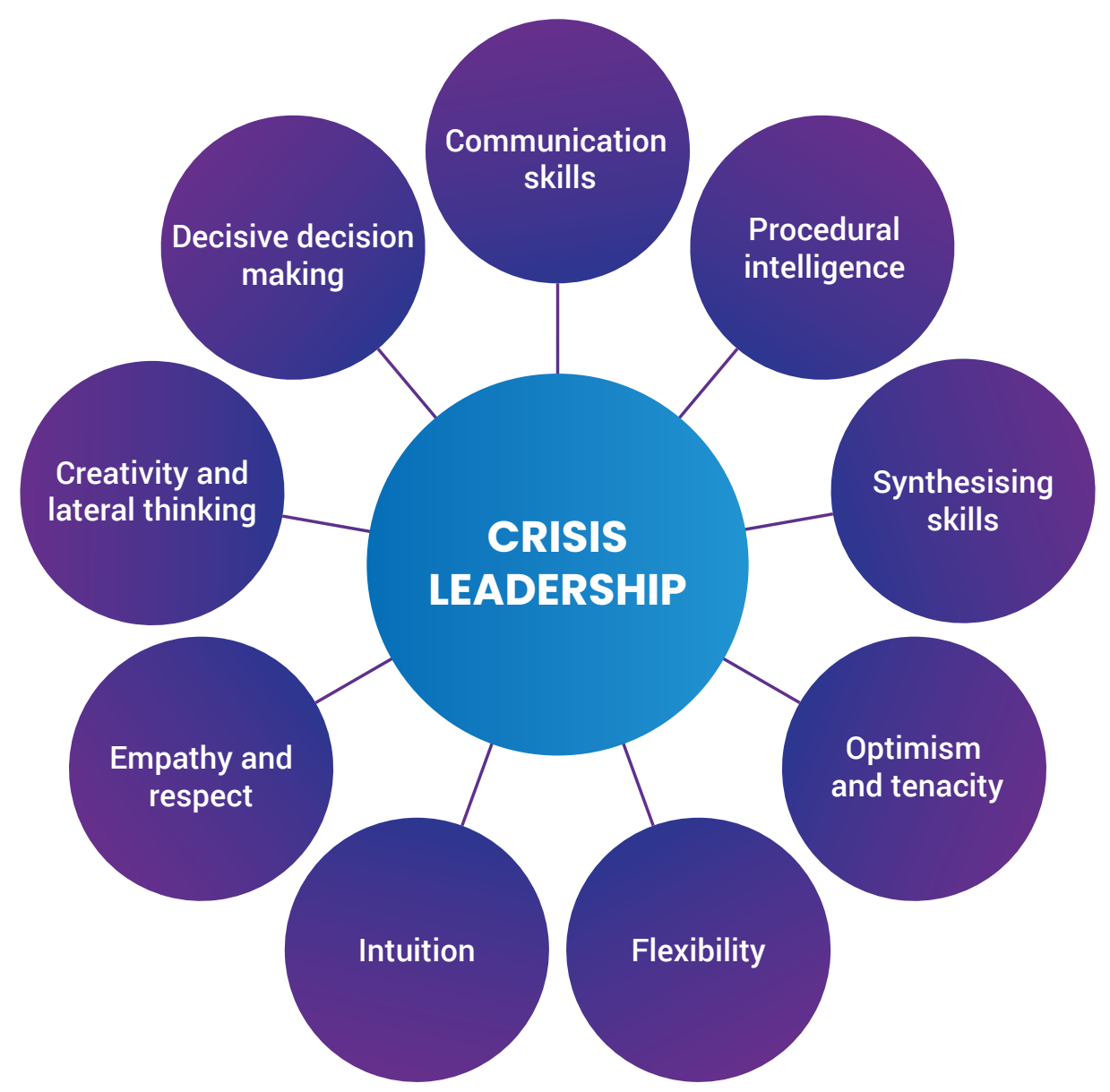

Figure 1. Key attributes for crisis leadership (adapted from Smith \& Riley, 2012, p.68).

\subsection{Implications for wellbeing}

When a crisis disrupts education, the first priority is physical health and security, followed closely by wellbeing. Literature from the New Zealand earthquakes is of relevance to the current pandemic situation. It emphasises the wellbeing of students, staff and families, and of "getting students back into good routines while managing anxiety" (Mutch, 2015, p.191). 


\subsubsection{Student wellbeing}

Providing children living in emergency and post-emergency situations with structured, meaningful, and creative activities in a school setting or in informal learning spaces improves their emotional and behavioural wellbeing (Burde et al., 2017, p. 620).

The period between an initial response and re-introduction of formal curriculum in the education in emergencies model is referred to as non-formal education. Several factors can improve students' wellbeing during this time and encourage a return to regular developmental patterns. These include:

- Social interaction with peers

- $\quad$ Support offered by adults

- $\quad$ Recognising the need for play

- $\quad$ Reinforcing the value of traditions (Nicolai, 2003, p. 32).

During an emergency in education response, wellbeing needs to be a priority for all students, irrespective of social and economic factors. The prevalence of mental health issues that can arise reinforces the need to address wellbeing for all.

Literature specific to the wellbeing of school students in the COVID-19 crisis is emerging, pointing to increased anxiety around the loss of schedules and routines, and feelings of isolation from a lack of direct contact/interaction with friends (Brazeau et al., 2020; Ziebell et al., 2020).

Social and emotional needs of children, with particular reference to what they miss when being at home in terms of socialisation/sharing with peers in a physical space is also being considered along with how wellbeing and health literacy should come to the fore when school resumes (Colao et al., 2020; Hargreaves, 2020; World Bank; 2020). In terms of enhancing student wellbeing when school resumes, there should be a "targeted strategy of physical re-engagement" (Brown et al., 2020, p.2), and ongoing promotion of healthy habits through the communication of health topics and healthy lifestyles using authentic learning activities. This can be supported by introduction of health literacy into school curricula, "either within scientific subjects or as extracurricular matter" (Colao et al., 2020, p.370).

Wellbeing is no longer a fad...It's now clear that without their teachers' care and support it's hard for many young people to stay well and focused... wellbeing is an essential precondition for achievement, especially among our most vulnerable children (Hargreaves, 2020, n.p.)

\subsubsection{Teacher wellbeing}

There is limited literature relating to teacher wellbeing in crisis situations, however, the research available shows that teacher wellbeing is context-specific and multi-faceted (Collie et al., 2012; Schleicher, 2018). The maxim "fit your own mask first" is reflected in empirical research which shows that teacher wellbeing materially affects the quality of learning (Jones et al., 2013; McCallum et al., 2017).

This is of concern when placed alongside findings from a recent survey from the Melbourne Graduate School of Education, which found that over $50 \%$ of primary and secondary teachers worked an extra six hours per week during the first round of school closures, and some indicated they worked an additional 20 hours or more (Ziebell et al., 2020, p.8). The same report documented teachers' concerns around their personal health and wellbeing while they were working from home, citing "feelings of isolation, physical workspace, excessive screen time and dealing with stress" (Ziebell et al., 2020, p.10). They also reported exhaustion due to the additional workload remote learning created, and anxiety on returning to the classroom due to the possibility of COVID-19 transmission. 


\section{QUALITY TEACHING AND LEARNING}

The literature reviewed in this section focuses on quality teaching and learning and its relationship to remote learning, specifically delivery modes, and remote teaching frameworks. The role of technology as an enabler for remote learning is considered in addition to differential learning outcomes for online versus in-class education (Rapid Research Information Forum, [RRIF], 2020).

In December 2019, the Council of Australian Governments (COAG) ${ }^{1}$ released the Alice Springs (Mparntwe) Education Declaration, and in April 2020 Australia's National Cabinet released the COVID-19 National Principles for School Education. Together these recognise that education in Australia "is best delivered by professional teachers to students in the classroom on a school campus" [emphasis added] (Brown et al., 2020, p.69). The National Cabinet recognised that "alternative flexible, remote delivery of education services may be needed" and did not reduce the expectation on schools to provide quality education, stating that "...all students must continue to be supported by their school to ensure participation in quality education during the COVID-19 crisis..." (Brown et al., 2020, p.69).

Quality education is supported by effective and purposeful educational programs that engage students, and by teachers trained in the use of these programs. Effective educational programs, whether they use technology or not, have a deliberate and planned learning design.

\subsection{Learning design}

Good learning design underpins engaging and effective learning experiences. Intentional design and planned high-quality interactive experiences can take months to develop when done properly (Hodges et al., 2020). The recent switch to remote learning happened rapidly, impacting on educator and school planning. If schools and education sectors set out to deliberately plan for learning that can be transferable across school and non-school settings, then a first step might be to examine different learning approaches, and pedagogical models (Appendix A). These models and approaches need to be appropriate for the context, purpose, and learner needs.

\subsubsection{Distance education research}

Distance learning is a complex balance of online content and physical interaction with content that is not delivered on a computer screen. Further, Australia is a vast country with many local communities who have unstable Internet access, therefore resources for offline learning-based opportunities need to be considered (AITSL, 2020).

The specialist distance education schooling sector can offer insights about effective practice in remote learning. Australia has been at the forefront of distance education delivery in the school sector since 1914, and since 1916 in NSW. The findings of the first major research into what worked in 'education by correspondence' (Cunningham, 1931) are useful to revisit during this crisis, as many themes are common to the current literature:

- The key to success in correspondence work for school children is cooperation between parents and teachers.

- It is advisable for students to work to a timetable that meets the convenience of the parent or home supervisor.

- It pays to insist on quality, rather than amount of work, from the very beginning.

- Achievement is a powerful stimulus. Care should be taken that each student achieves some success in each assignment.

1 Council of Australian Governments through its Education Council. 
- Educational diagnosis is a very important feature of the work.

- Full advantage should be taken of the possibilities which correspondence instruction affords in the way of flexibility of grading and promotion.

- Encouraging reading on a wide-scale. A good library of selected books is an almost indispensable adjunct to a correspondence school.

- Cultivating an intelligent interest in their own environment.

- Coordination and cooperation between centres [emphasis has been added] (adapted from Cunningham, 1931, pp. 68-72).

Distance education research has continued to build from here.

\subsubsection{Blended learning research}

Adopting a blended learning approach offers the appeal of combining different learning elements using the power of ICT while retaining a human touch (DEECD, 2012, p.34).

Blended learning is a common approach in the Higher Education sector where students learn both on and off-campus, and consequently there is a myriad of research on this topic (Pima et al., 2018). Emerging literature in the school sector has been described as limited and lacking in controls (Poirier et al., 2019). In the light of current restrictions there is renewed impetus for re-examining the benefits of providing blended programs which combine face-to-face and online learning (Brown et al., 2020).

There is Australian evidence to suggest that "blended learning may be as effective as classroom learning for many students" (Brown et al., 2020, p.1). For example, the "eKids Framework that has been supporting blended learning for rural and remote students for the past decade found significantly better educational outcomes from blended learning compared to classroom or online delivery" (Brown et al., 2020, p.2). A blended learning approach is not new to New South Wales (CEP, 2014; NSW DEC, 2013), rather it has come to the forefront as a proposed change in approach to education post-pandemic.

\subsubsection{Online learning research}

There is over two decades of robust research in the area of online learning design, predominantly from the Higher Education sector (Roddy et al., 2017). A great deal of research effort has been expended in trying to determine whether online learning is more or less effective than traditional face-to-face models (Means et al., 2013).

When students and teachers have the right training and preparation there is some evidence that older students retain more knowledge from online learning than in the face-to-face classroom, while younger students require a more structured environment with scaffolding and support (ACER, 2020; Li \& Lalani, 2020). However, the current COVID-19 crisis has presented a situation quite different from previous approaches to online study for both teachers and students in terms of readiness, appropriate tools and resources, lack of design support, and issues with infrastructure (ACER, 2020; AITSL, 2020; Erturk \& Ekundayo, 2020, Hodges et al., 2020). Teachers need to be involved in planning so that technology fits with instructional needs, however the sudden changes to educational delivery prevented this, and additionally teachers need time to upskill in facilitation techniques and assessment practices if teaching is offered solely in online mode (ACER, 2020; INEE, 2020). 


\section{THE ROLE OF TECHNOLOGY}

Debates about screen time have shifted from a focus on quantity to quality (AITSL, 2020).

The best practice in the integration of technology and education is where pedagogy is at the forefront. The development of a variety of digital skills, and having an efficient infrastructure both at home and at school are also key to success in the smooth roll-out of technology (ACER, 2020; AITSL, 2020; World Bank, 2020).

Effective practice can be negatively impacted by the use of unsuitable products, such as 'off-the-shelf' education solutions. The premise underlying many off-the-shelf products is that education can be packaged, automated, personalised and delivered - at scale - and at low cost. There are concerns around the risks and restrictions of these proprietary platforms and 'quick fix' digital solutions, and the related issues around data-mining student information (Facer \& Selwyn, 2013; Player-Koro et al., 2018; Selwyn et al., 2020).

\subsection{Teacher and student readiness and capability}

Creative approaches to teaching and learning, and adaptability and resilience are highly desirable traits (Bartley et al., 2018, n.p.).

A majority of teachers have not been prepared for the challenge of working in inherently different environments from the regular classroom. "Where online learning, and tools to support online learning, are already a constituent part of what an education system (or an individual school) is able to provide, the potential for success is greater" (World Bank, 2020, p. 2). However, the effectiveness of remote learning online will depend on teacher and student readiness and capability (AITSL, 2020; RRIF, 2020) - teaching online differs greatly from teaching in the classroom. "Teaching exclusively online requires a different skill set than teaching face-to-face" and even experienced teachers can struggle when "operating in a wholly online environment" (World Bank, 2020, p.7).

Research also tells us "that just like in the regular classroom, good learning using technology requires teacher presence; not just for social interaction but to guide and facilitate learning" (Angeli et al., 2003; AITSL, 2020; Hodges et al., 2020). This does not mean that the teacher or student should be constantly in contact on a screen over the period of the school day, but rather, learning involves an appropriate balance of teacher-directed, group and individual work that includes synchronous and asynchronous activity. A three-pronged approach to remote learning, developed in Singapore over a period of three years, is relevant to the current Australian context. The approach is to strengthen student-teacher interaction; plan regular checkpoints with live student responses; and utilise student interaction (Fung et al., 2020). 


\subsection{Access}

Access means ensuring learners everywhere are not prevented by circumstances from being in school and getting an education (Krishnan, 2020, para 8).

Access to resources for learning is often related to underlying social issues which, although beyond the control of schools, need consideration when delivering remote learning. Expert analysis provided to Australia's Chief Scientist in April 2020 also indicated that one of the factors likely to moderate the effectiveness of remote learning is access to digital technology and the Internet (RRIF, 2020, p.1). Ideally, all students will have access to, and skills in, using appropriate hardware and software, and teachers will have skills in, and access to, good online learning curriculum resources and be skilled in online pedagogy.

Whilst technology is one way that schools can address continuity of teaching and learning, the 2019 Australian Digital Inclusion Index shows that, although the overall index has increased since 2017 across all three dimensions of digital inclusion: access, affordability and digital ability, there are substantial and widening gaps for some groups (Brown et al., 2020; Thomas et al., 2019). There are inequalities in both developed and non-developed countries. For example, there is a substantial digital divide between richer and poorer Australians, regardless of location (Krishnan, 2020; Thomas et al., 2019).

Current literature suggests mitigation strategies such as optimising content for low bandwidth, and offline approaches such as making content available in PDF format for download before class, and offering shorter video snippets (AITSL 2020; World Bank, 2020). 


\section{CONTEXT IS IMPORTANT}

Students with effective access to technology at home (and hence, online delivery of learning) may have progressed well in their learning during the study at home period, while other students with no, or limited access, and/or students with additional learning needs, may have made limited progress (Leonard \& Brown, 2020, n.p.).

Context is important; one size cannot fit all. Best practice in remote teaching needs to be responsive to different contexts and cannot rely solely on technology. Understanding the impacts of learning in the home environment requires knowledge of specific experiences during school closures (AITSL, 2020; Brown et al., 2020). As an example, initial research suggests that online learning in remote contexts is easier for older and motivated students than it is for younger students who generally require, and are used to a structured learning environment (Brown et al., 2020; Li \& Lalani, 2020; World Bank, 2020).

\subsection{Differentiation}

Differentiated teaching is a method that is used to extend the knowledge and skills of every student, regardless of their starting point, with the aim of improving the performance of every student. By examining the role technology can play in creating personalised and differentiated learning, students can get the type of instruction they need to succeed (AITSL, 2020; Moyle, 2012; Sonnemann \& Goss, 2020).

Well-designed learning activities can be used to monitor student progress and provide data that help teachers to identify each students' strengths and weaknesses. This facilitates tailoring of learning to suit individual needs. Data are used to differentiate classrooms by applying different teaching approaches to small classes or small groups of students within the class (Moyle, 2012). However, "targeted teaching is not easy; teachers require high levels of data literacy as well as good diagnostic skills to tailor their teaching to student needs" (Sonnemann \& Goss, 2020, p.26).

Adopting effective pedagogical approaches enables teachers to set goals and targets related to the context of individuals and distinct groups of students. Evidence shows small group tuition improves student achievement, especially for disadvantaged students, and sustained support will help students catch up (Education Endowment Foundation, 2020; Sonnemann \& Goss, 2020). Targeted support of this kind might be beneficial as educators seek to provide support for students with a wide range of additional needs as the ongoing COVID-19 disruption is navigated. 


\section{THE HOME LEARNING ENVIRONMENT}

It is important to recognise that some children will thrive and adapt easily to the new learning environment, that some children and schools are more prepared for this, and that for some children, this will serve to further amplify their learning disadvantage (Thomson, 2020).

There is agreement that the home learning environment and associated home context are factors that impact on the success of remote learning (RRIF, 2020, p.1). Resources, including families' time, income, and human, social, and psychological capital are differentially distributed across and within families, and impact upon the kind of support that parents and caregivers are able to provide to support children's learning.

A home environment suitable for learning is one that has a designated area to do homework, provides access to reading material, and where a student has access to assistance with studies (OECD, 2012).

\subsection{The role of parents and caregivers}

There is strong evidence that parent engagement is associated with significant improvements in academic achievement for students of all ages (DESE, 2017, p.1).

Parental involvement ${ }^{2}$ in children's learning is important regardless of mode of delivery, and the quality of the home learning environment is associated with improved academic outcomes at all ages (ACER, 2016; AITSL, 2020; Castro et al., 2015; DESE, 2017; Emerson et al., 2012, Sammons et al., 2015).

Involving parents in learning has a greater impact on improving student outcomes than socio-economics (Desforges \& Abouchaar, 2003; Goldman, 2005; DESE, 2017). Studies of parental involvement in schooling show that interactions are most effective when voluntary (Jeynes, 2012), when there is a clear understanding of the roles of parents and teachers in learning (Emerson et al., 2012), and where partnerships have a deliberate focus on learning and wellbeing (ACER, 2016).

Recent studies on the role of parents/caregivers in student learning (Education Endowment Foundation, 2020; Evidence for Learning, 2019) emphasise that the role of the caregiver is not to replace the teacher, but rather to support the learning of the child. The nature of support needs to be different depending on the age of the child, for example:

Parents/caregivers can support their children's learning by helping them to develop independent learning skills, and schools can help parents by providing practical strategies and materials to support learning at home (ACER, 2020). There are particular skills recognised as "important for children to develop at different ages and stages" (Evidence for Learning, 2019, p.7) including:

- In the early years, activities that develop oral language and self-regulation

- In early primary, activities that target reading (for example, letter sounds, word reading, and spelling) and numeracy (such as learning numbers or learning the count sequence)

- In later primary, activities that support reading comprehension through shared book reading

- In secondary school, independent reading and strategies that support independent learning.

Australian data to June 2020 showed that the proportion of people always working from home rose from $7 \%$ before COVID-19 to $60 \%$ during the pandemic. While working from home, $40 \%$ of parents always or often cared for children during work (Hand et al., 2020).

2 Parental involvement/engagement includes caregivers, grandparents, or extended family. 
A unique feature of the current school and workplace closures is multi-tasking; adults playing multiple roles as parents, carers, and employees. Parents are supervising their own children while working, and some are worrying about not working as unemployment continues to rise. These factors have led to increased stress in households, and reduced access to family support services, with initial evidence suggesting a subsequent increased risk to child safety (Brown et al., 2020; O'Donnell et al., 2020; Teo \& Griffiths 2020).

\subsection{Implications for learning from home}

The review of relevant literature confirmed that a range of social, health, economic, and technical factors can impact on learning at home. Parents and caregivers play a crucial role in remediating educational disadvantage, however, the level of education, socio-economic status, and capacity to provide home learning support and resources for students is lower among parents of educationally disadvantaged students. Pre-pandemic data from international studies such as the Progress in International Reading Literacy Study - Year 4 (PIRLS, 2016) also show that educational vulnerability is exacerbated by reduced access to a range of resources at home, for example, adequate food and shelter, information and communication technologies, a quiet place to work, books, and learning support from parents.

Resources and strategies need to be attentive to particular circumstances and contexts. For example, "low-income households and those in remote areas have on average half as many desktop, laptop or tablet computers as middleincome households" (RRIF, 2020, p. 3). Supporting this, Hattie (2020), notes that "the most likely implication of school closures relates to equity. Students who come from well-resourced families will fare much better than those from lower resourced families" (para 7).

\subsection{Social and educational vulnerability}

Education is known to provide a critical role in the care and protection for vulnerable ${ }^{3}$ groups. A hidden cost of school shutdowns is the likelihood of increased vulnerability (ACER, 2020; Baron et al., 2020; Shlonsky et al., 2020).

Almost half (46\%) of all Australian school children and young people are at risk of adverse effects on their "educational outcomes, nutrition, physical movement and emotional wellbeing by being physically disconnected from school" (Brown et al., 2020, p.5). Recognising this risk, the Australian Government commissioned a set of research that examined the potential impact of remote learning from home on educational outcomes for vulnerable cohorts of children. This research considered barriers to access, and sought evidence-informed responses (ACER, 2020; Brown et al., 2020; Clinton, 2020; Lamb, 2020; O'Shea, 2020).

Emerging literature has highlighted that students at particular risk of poorer learning outcomes include those from low socioeconomic backgrounds, those with English as a second language, young people who faced persistent disadvantage pre-pandemic (Brown et al., 2020; Hattie, 2020), students with "special learning needs and those in rural and remote areas" (RRIF, 2020, p. 1), children in the early years of schooling, and older students who are in VET subjects and unable to undertake practicums (Brown et al., 2020).

The literature indicates remote-learning programs do exist and may be leveraged to help the learning of students at home. However, the basic human needs of students must first be met in order for education programs to be able to succeed (Zubrick et al., 2005). The likelihood of any positive impact from educational programs on vulnerable students will be greatly increased if support is also provided to deal with their basic needs, including care and protection.

3 Vulnerability is considered from two interrelated perspectives: social and educational. Socially vulnerable children are over-represented among the group of students who are educationally vulnerable. 
Responses to support vulnerable students and mitigate this risk have been documented by Shlonsky et al., (2020), and O'Donnell et al., (2020). Strategies relevant to this review include:

- The continued and sustained financial support for families who suffer income and job loss

- Online consultations for mental health and addiction, so service provision is broader than just tele-health and includes community-based support services

- Urgent support for service providers to develop policy on how to safely sustain service provision in the event of a community lockdown

- Refuges/emergency accommodation for those seeking safety

- Flexible, innovative strategies, such as respite services and child care provisions for in-home support for families and carers who are vulnerable or who have children with high care needs

- Extend care in 2020 for young people turning 18 so they can remain in out-of-home care placements

- Increase the workforce capacity for welfare and community agencies

and

- Ensure "schools have a targeted strategy of physical re-engagement" (Brown et al., 2020, p.2)

- Maintain the child protection workforce to protect vulnerable groups of children (Teo \& Griffiths, 2020).

\subsection{Resources to enable remote learning}

\subsubsection{Books}

Promoting reading at home is a practical strategy suggested in the Working with parents to support children's learning report (Evidence for Learning, 2019). Research highlights the importance of reading, and in an ideal situation, students would have access to books at home. This is recognised as promoting educational success into adulthood (Evans et al., 2010, Evidence for Learning, 2019, PIRLS, 2016, Sikora et al., 2019). The provision of books is a cost-effective response, both during and post-COVID 19 (ACER, 2020).

\subsubsection{Online resources}

Australian education sector and professional association websites have provided a wide range of online resources since the start of the school closures, examples are the AITSL website, the Australian Literacy Educators' Association website, and ABC Education.

The Virtual School Victoria Pedagogical Model for Virtual Learning (Remote Schools Victoria, 2018), is an existing online resource, see Appendix A. There are other online evidence-based resources which are readily-available for parents/ caregivers (for example, Evidence for Learning, 2019) - although the resource was designed for a non-pandemic situation, it is applicable to remote learning.

Schools require infrastructure and trained technical support staff to support good remote learning. Ideally, schools will use a Learning Management System (LMS); a purpose-built, cybersafe environment for online learning. An LMS has integrated tools to support synchronous and asynchronous learning, so that students and teachers can collaborate, and teachers can monitor individual learning. 


\section{CONCLUSION}

This review has drawn upon bodies of literature about education in emergencies, access and equity, wellbeing, quality teaching and learning, technology, and home schooling to identify good practice for remote teaching and learning.

This review highlights:

- $\quad$ That technology supplements, but does not replace, teaching. Successful remote teaching requires teachers and students to have access to appropriate resources, including technology, and well-designed learning environments. It is critical that teachers are provided with appropriate support and professional learning in each of these, particularly in designing learning which makes use of effective digital pedagogies.

- During, immediately post-pandemic, and into the future, it is vital to focus on the health and wellbeing of students and teachers, and health literacy should be included in the curriculum.

- $\quad$ The need for clear messaging from school leaders to key stakeholders and all members of the school community during remote learning periods, and on (each) return to the classroom.

- The importance of parental involvement in learning and strong school-community-family relationships.

- Increased educational vulnerability due to studying at home.

- The need for a strategy that includes physical and social re-engagement and differentiated learning on return to the classroom, so that no child is left behind. 


\section{DEFINITIONS}

For the purposes of this review the following definitions are relevant, noting that it is Emergency Remote Teaching that best characterises the response of Australian schools' to the COVID-19 crisis.

\section{Blended learning}

Education designed to use both synchronous and asynchronous delivery, and/or to use both online and in-person learning experiences when teaching students. It is sometimes referred to as hybrid learning (EdGlossary, 2013).

\section{Distance learning}

Distance education is "institution based, formal education where the learner group is separated and where interactive communications systems are used to connect learners, resources, and instructors" (Schlosser \& Simonson, 2019).

\section{Emergency Remote Teaching}

Emergency Remote Teaching (ERT) is a temporary shift of instructional delivery to an alternative delivery mode due to crisis circumstances (Hodges et al., 2020). It involves the use of fully remote teaching solutions for instruction or education that would otherwise be delivered face-to-face or as blended or hybrid study, and that will return to that format once a crisis or emergency has abated (Zubrick et al., 2005). The primary objective in these circumstances is to provide temporary access to instruction and instructional supports in a manner that is quick to set up and is reliably available during an emergency or crisis.

\section{Online learning}

Online learning involves students having anytime, anywhere access to course materials which are carefully prepared and designed for asynchronous learning (Means et al., 2014). Online learning involves purposeful instructional design and planning, and is delivered through a specially-designed, secure learning environment, for example a Learning Management System (LMS).

\section{Remote learning}

Remote learning is a short-term mitigation option to act as a replacement for face-to-face teaching. It provides temporary access to instruction and instructional supports. "Remote learning provides an opportunity for students and teachers to remain connected and engaged with content while working from their homes. Opportunities for remote learning are typically linked to emergency situations that pose a threat to student safety" (Ray, 2020, p. 4). 


\section{REFERENCES}

Angeli, C., Valanides, N., \& Bonk, C. (2003). Communication in a web-based conferencing system: The quality of computer-mediated interactions. British Journal of Educational Technology, 34(1): 31-43. https://doi. org/10.1111/1467-8535.d01-4

Arantes, J. A. (2020). The servitization of Australian K-12 educational settings. Postdigital Science and Education. https://doi.org/10.1007/s42438-019-00097-0

Australian Catholic University. (2011). Issues Paper 7: Equity and Education. https://isa.edu.au//wp-content/ uploads/2017/02/PPI-Paper-1-Equity-and-Education.pdf

Australian Council for Educational Research (ACER). (2016). National School Improvement Tool. https:// research.acer.edu.au/tll_misc/18

Australian Council for Educational Research (ACER). (2020). Ministerial Briefing Paper on Evidence of the Likely Impact on Educational Outcomes of Vulnerable Children Learning at Home during COVID-19. https://research.acer. edu.au/learning_processes/24

Australian Literacy Educators Association. (2020). https://alea.edu.au

Australian Institute for Teaching and School Leadership (AITSL). (2020). Spotlight. What works on online/ distance teaching and learning? https://www.aitsl.edu. au/research/spotlight/what-works-in-online-distanceteaching-and-learning

Bano, M., Zowghi, D., Kearney, M., Schuck, S. \& Aubusson, P. (2018). Mobile learning for science and mathematics school education: A systematic review of empirical evidence. Computers \& Education, 127, 30-58. https://doi. org/10.1016/j.compedu.2018.02.006

Baron, E. J., Goldstein, E. G., \& Wallace, C. T. (2020). Suffering in silence: How Covid-19 school closures inhibit the reporting of child maltreatment (SSRN Scholarly Paper ID 3601399). Social Science Research Network; https://doi.org/10.2139/ssrn.3601399. https:// doi.org/10.2139/ssrn.3601399

Bartley, J., Jorgenson, M. Pierce, K. \& Simmalavong, B. (2018). Learning program design and teacher capacity: A literature review. Distance Education Centre Victoria. http://www.distance.vic.edu.au/wp-content/ uploads/2018/10/Learning-Program-DesignandTeacher-Capacity.pdf
Battenfeld, M. (2020, June 16). 3 lessons from how schools responded to the 1918 pandemic worth heeding today. The Conversation. http:// theconversation.com/3-lessons-from-how-schoolsresponded-to-the-1918-pandemic-worth-heedingtoday-138403

Bond, M. (2020). Facilitating student engagement through the flipped learning approach in K-12: A systematic review. Computers \& Education, 151, 103819. https://doi. org/10.1016/j.compedu.2020.103819

Brazeau, G. A., Frenzel, J. E., \& Prescott, W. A., Jr (2020). Facilitating wellbeing in a turbulent time. American Journal of Pharmaceutical Education, 84(6), ajpe8154. https://doi.org/10.5688/ajpe8154

Brown, N., Te Riele, K., Shelley, B. \& Woodroffe, J. (2020). Learning at home during COVID-19: Effects on vulnerable young Australians. Independent Rapid Response Report. Hobart: University of Tasmania, Peter Underwood Centre for Educational Attainment. https:// www.dese.gov.au/system/files/doc/other/learning_at_ home_during_covid_30042020.pdf

Burde, D., Kapit, A., Wahl, R. L., Guven, O., \& Skarpeteig, M. I. (2017). Education in emergencies: A review of theory and research. Review of Educational Research, 87(3), 619-658. https://doi.org/10.3102/0034654316671594

Burden, K., Kearney, M., Schuck, S., \& Burke, P. (2019). Principles underpinning innovative mobile learning: Stakeholders' priorities. TechTrends 63(6), 659-668. https://doi.org/10.1007/s11528-019-00415-0

Castro, M., Exposito-Casas, E., Lopez-Martin, E., Lizasoain, L., Navarro-Asencio, E. \& Gaviria, J. J. (2015) 'Parental involvement on student academic achievement: A meta-analysis', Educational Research Review, 14, 33-46. https://doi.org/10.1016/j.edurev.2015.01.002

Cavanaugh, C. S., Gillan, K. J., Kromrey, J., Hess, M., \& Blomeyer, R. (2004). The effects of distance education on K-12 student outcomes: A meta-analysis. Learning Point Associates. https://files.eric.ed.gov/fulltext/ED489533. pdf

Chase, A.-M., \& Taylor-Guy, P. (2020, March 27).

Covid-19: Continuity of teaching and learning - an evidence-based approach. Teacher. https://www. teachermagazine.com.au/articles/covid-19-continuityof-teaching-and-learning-an-evidence-based-approach 
Clinton, J. (2020). Supporting vulnerable children in the face of a pandemic. Melbourne Graduate School of Education. https://www.dese.gov.au/system/files/doc/ other/clinton_supporting_vulnerable_children_final.pdf

Colao, A., Piscitelli, P., Pulimeno, M., Colazzo, S., Miani, A., \& Giannini, S. (2020). Rethinking the role of the school after COVID-19. The Lancet Public Health, 5(7), e370. https://doi.org/10.1016/S2468-2667(20)30124-9

Collie, R. J., Shapka, J. D., \& Perry, N. E. (2012). School climate and social-emotional learning: Predicting teacher stress, job satisfaction, and teaching efficacy. Journal of Educational Psychology, 104(4), 1189

Country Education Partnership (CEP). (2014). eKids Framework. https://cep.org.au/wp-content/ uploads/2020/04/eKids-Framework-2014.docx

Cunningham, K.S. (1931). Primary education by correspondence: Being an account of the methods and achievements of the Australian Correspondence Schools in instructing children living in isolated areas. Melbourne University Press. https://research.acer.edu.au/learning_ processes/25

Department of Education and Early Childhood Development (DEECD). (2012). Blended learning: A synthesis of research findings in Victorian education 20062011. https://www.education.vic.gov.au/Documents/ about/research/blendedlearning.pdf

Department of Education and Training (DET) Victoria (2020, May 28). Top tips for effective online learning: The teachers at Virtual School Victoria have compiled their top insights into how teachers can best engage learning from home students. https://www.education. vic.gov.au/school/teachers/classrooms/Pages/ approachesonlinelearningtoptips.aspx

Department of Education, Skills and Employment (DESE). (2017, May 29). Parent Engagement Research. https:// docs.education.gov.au/node/43976

Department of Education, Skills and Employment (DESE). (2020, April 16). COVID-19 National Principles for School Education. https://www.dese.gov.au/covid-19/schools/ national-principles-for-school-education

Desforges, C., \& Abouchaar, A. (2003). The impact of parental involvement, parental support and family education on pupil achievement and adjustment: A literature review (Vol. 433). London: DfES.

Dixon, M. (2020). Social media as a professional space during lockdown. Metaphor, 2, p. 20-21.
Drane, C., Vernon, L., \& O'Shea, S. (2020). The impact of 'learning at home' on the educational outcomes of vulnerable children in Australia during COVID-19 pandemic. National Centre for Student Equity in Higher Education. https://www.dese.gov.au/system/files/doc/ other/final_literaturereview-learningathome-covid19final_28042020.pdf

Duan, A. (2020). The double-edged sword of remote learning. Connect, 243, 8-9. https://research.acer.edu. au/connect/vol2020/iss243/1/

EdGlossary. (2013). Asynchronous learning. https://www. edglossary.org/asynchronous-learning/

EdGlossary. (2013). Blended learning. https://www. edglossary.org/blended-learning

EdGlossary. (2013). In-person learning. https://www. edglossary.org/in-person-learning

Education Endowment Foundation. (2020). Evidence for Learning Early Childhood Education Toolkit: Education Endowment Foundation. https://evidenceforlearning. org.au/the-toolkits/early-childhood-education-toolkit

Emerson, L., Fear, J., Fox, S., \& Sanders, E. (2012). Parental engagement in learning and schooling: Lessons from research. A report by the Australian Research Alliance for Children and Youth (ARACY) for the Family-School and Community Partnerships Bureau: Canberra.

Erturk, E., \& Ekundayo, S. (2020, July 10). Designing the emergency online study bubble. EdArXiv Preprints. https:// doi.org/10.35542/osf.io/gkmv6

Escueta, M., Quan, V., Nickow, A. \& Oreopoulos, P. (2017) Education technology: An evidence-based review. National Bureau of Economic Research. https://www.nber.org/ papers/w23744

Evans, M. D. R., Kelley, J., Sikora, J., \& Treiman, D. J. (2010). Family scholarly culture and educational success: Books and schooling in 27 nations. Research in Social Stratification and Mobility, 28(2), 171-197. https://doi. org/10.1016/j.rssm.2010.01.002

Evidence for Learning. (2019). Working with parents to support children's learning. Sydney. https:// evidenceforlearning.org.au/assets/Guidance-Reports/ Parental-engagement/Guidance-Report-Working-withParents-to-Support-Childrens-Learning-WEB.pdf

Facer, K., \& Selwyn, N. (2013). The politics of education and technology: conflicts, controversies and connections. Palgrave. 
Fraillon, J., Ainley, J., Schulz, W., Friedman, T., \& Gebhardt, E. (2014). Preparing For Life in a Digital Age: IEA International Computer and Information Literacy Study 2013 International Report. Springer. https://research. acer.edu.au/ict_literacy/8

Fung, F. M., Magdeline, N. T. T., \& Kamei, R. K. (2020, June 10). How to create engaging online learning amid COVID-19 pandemic: Lessons from Singapore. The Conversation. http://theconversation.com/howto-create-engaging-online-learning-amid-covid-19pandemic-lessons-from-singapore-138979

Goldman, R. 2005. Fathers' involvement in their children's education. National Family and Parenting Institute.

Greenberg, M. T., Brown, J. L. \& Abenavoli R. M. (2016) Teacher Stress and Health. Pennsylvania State University. http://www.rwjf.org/content/dam/farm/ reports/issue_briefs/2016/rwjf430428

Halsey, J. (2018). Independent Review into Regional, Rural and Remote Education: Final Report. Australian Government Department of Education and Training. https://docs.education.gov.au/node/50281

Hand, K., Baxter, J., Carroll, M., \& Budinski, M. (2020). Families in Australia Survey: Life during COVID-19 (Report No. 1). Australian Institute of Family Studies. https://aifs.gov. au/sites/default/files/publication-documents/covid-19survey-report_1_early_findings_0.pdf

Hargreaves, A. (2020, April 17). What's next for schools after coronavirus? Here are 5 big issues and opportunities. The Conversation. http://theconversation. com/whats-next-for-schools-after-coronavirus-hereare-5-big-issues-and-opportunities-135004

Hattie, J. (2020, April 14). Visible Learning effect sizes when schools are closed: What matters and what does not. Corwin Connect. https://corwin-connect. com/2020/04/visible-learning-effect-sizes-whenschools-are-closed-what-matters-and-what-does-not

Hodges, C., Moore, S., Lockee, B., Trust, T., \& Bond, A. (2020, March 27). The difference between emergency remote teaching and online learning. Educause Review. https://er.educause.edu/articles/2020/3/thedifference-between-emergency-remote-teaching-andonline-learning

Inter-agency Network for Education in Emergencies (INEE). (2020). Technical Note: Education during the COVID-19 Pandemic. https://inee.org/resources/ineetechnical-note-education-during-covid-19-pandemic
Ismail, I., Bokhare, S. F., Azizan, S. N., \& Azman, N. (2013). Teaching via mobile phone: A case study on Malaysian teachers' technology acceptance and readiness. Journal of Educators Online, 10(1). https://files.eric. ed.gov/fulltext/EJ1004895.pdf

Kearney, M., Burke, P., \& Schuck, S. (2019). The iPAC scale: A survey to measure distinctive mobile pedagogies. TechTrends, 63(6), 751-764. https://doi.org/10.1007/ s11528-019-00414-1

Krishnan, K. (2020, April 13). Our education system is losing relevance. Here's how to update it. World Economic Forum Agenda. https://www.weforum.org/ agenda/2020/04/our-education-system-is-losingrelevance-heres-how-to-update-it

Jeynes, W. (2012). A meta-analysis of the efficacy of different types of parental involvement programs for urban students. Urban Education, 47(4), 706-742. https://doi.org/10.1177/0042085912445643

Jones, S.M., Bouffard, S.M., \& Weissbourd, R. (2013). Educators' social and emotional skills vital to learning. Phi Delta Kappan, 94(8), 62-65. https://doi. org/10.1177/003172171309400815

Lamb, S. (2020). Impact of learning from home on educational outcomes for disadvantaged children. Mitchell Institute, Victoria University. https://www.dese. gov.au/system/files/doc/other/lamb_-_impact_of_ learning_from_home.pdf

Li, C., \& Lalani, F. (2020, April 29). The COVID-19 pandemic has changed education forever. This is how. World Economic Forum Agenda. https://www.weforum.org/ agenda/2020/04/coronavirus-education-globalcovid19-online-digital-learning

Leonard C., \& Brown, G. (2020, May 12). COVID-19: How teachers can help students transition back to school. Teacher. https://www.teachermagazine.com.au/ articles/covid-19-how-teachers-can-help-studentstransition-back-to-school

McCallum, F., Price, D., Graham, A., \& Morrison, A. (2017). Teacher wellbeing: A review of the literature. AISNSW. https://apo.org.au/node/201816

Means, B., Bakia, M., \& Murphy, R. (2014). Learning online: What research tells us about whether, when and how. Routledge.

Means, B., Toyama, Y., Murphy, R., \& Baki, M. (2013). The effectiveness of online and blended learning: A metaanalysis of the empirical literature. Teachers College Record, 175(3), 1-47. 
Moyle, K. (2012). Differentiated classroom learning, technologies and school improvement: What experience and research can tell us. Charles Darwin University, NT. https://research.acer.edu.au/cgi/viewcontent. cgi? article $=1135 \&$ context $=$ research_conference

Mullis, I. V. S. Martin, M. O., \& Sainsbury, M. (2015). PIRLS 2016 Reading Framework (2nd Ed.). Boston College. http://timssandpirls.bc.edu/pirls2016/framework.html

Mutch, C. Smith, L., \& Riley, D. (2012). School leadership in times of crisis. School Leadership and Management, $32(1), 57-7$.

Mutch, C. (2013). "Sailing through a river of emotions": Capturing children's earthquake stories. Disaster Prevention and Management, 22, 445-55.

Mutch, C. (2014). The role of schools in disaster settings: Learning from the 2010-2011 New Zealand earthquakes. International Journal of Educational Development, 41, 283-291.

Mutch, C. (2015). Quiet heroes: Teachers and the Canterbury, New Zealand, earthquakes. Australasian Journal of Disaster and Trauma Studies, 19(2).

National Standards for Quality Online Teaching 3rd Ed. (2019). Virtual Learning Leadership Alliance \& QM Quality Matters.https://www.nsqol.org/the-standards/qualityonline-teaching

NSW Department of Education and Communities. (2013) Rural and Remote Education: A blueprint for action. https://education.nsw.gov.au/content/dam/maineducation/teaching-and-learning/curriculum/media/ documents/Rural-and-Remote-Education-Blueprintaccessible.pdf

NSW Department of Education. (2020). Parents and carers. Teaching and Learning. https://education.nsw. gov.au/teaching-and-learning/learning-from-home/ wellbeing-at-home/parents-and-carers.html

Nichols, M. (2018). Addendum: Reading and studying on the screen. Journal of Open Flexible and Distance Learning, 22(2), 49-60. http://www.jofdl.nz/index.php/ JOFDL/article/view/347

Nicolai, S (2003). Education in Emergencies: A tool kit for starting and managing education in emergencies. Save the Children, London. https://resourcecentre. savethechildren.net/node/3299/pdf/3299.pdf

Nye, A. (2016). 'Working from the boot of a red Falcon': The impact of major fires in four Australian schools. Australian and International Journal of Rural Education, 26(1), 83-98.
Nye, A. (2017). Rebuilding schools after fire. Linking Research to the Practice of Education, 7(1), 3-4. https:// www.une.edu.au/_data/assets/pdf_file/0012/172002/ soe_newsletterv1.1.pdf

O'Connor, P., \& Takahashi, N. (2014). From caring about to caring for: Case studies of New Zealand and Japanese schools post disaster. Pastoral Care in Education, 32(1), 42-53. https://doi.org/10.1080/02643944.2013.8755 84

O'Donnell, M., Shlonsky, A., Mathews, B., Arney, F., Stanley, F., Bromfield, L., Pilkington, R., \& Marriott, R. (2020, April 8). What governments can do about the increase in family violence due to coronavirus. The Conversation. https://theconversation.com/what-governmentscan-do-about-the-increase-in-family-violence-due-tocoronavirus-135674

OECD. (2012), Equity and Quality in Education: Supporting Disadvantaged Students and Schools, OECD Publishing. http://dx.doi.org/10.1787/9789264130852-en

OECD. (2020, March 23). Education responses to COVID-19: Embracing digital learning and online collaboration.https://www.oecd.org/coronavirus/ policy-responses/education-responses-to-covid-19embracing-digital-learning-and-online-collaborationd75eb0e8

OHCHR. (1989). Convention on the Rights of the Child. https://www.ohchr.org/en/professionalinterest/pages/ crc.aspx

OHCHR. (1990). World Declaration on Education for All. https://www.ohchr.org/EN/Issues/ Education/Training/Compilation/Pages/9. WorldDeclarationonEducationforAll(1990).aspx

Overseas Development Unit (ODI). A common platform for education in emergencies and protracted crises: Evidence paper. https://www.alnap.org/system/files/content/ resource/files/main/evidence-paper-education-inemergencies.pdf

Pérez-Sanagustín, M., Nussbaum, M., Hilliger, I., AlarioHoyos, C., Heller, Rachelle S., Twining, P., \& Tsai, C. (2017). Research on ICT in K-12 schools: A review of experimental and survey-based studies in Computers \& Education 2011 to 2015. Computers and Education, 104, A1-A15. https://doi.org/10.1016/j. compedu.2016.09.006

Pima, J. M., Odetayo, M., Iqbal, R., \& Sedoyeka, E. (2018). A thematic review of blended learning in higher education. International Journal of Mobile and Blended Learning, 10(1), 1-11. https://doi.org/10.4018/ IJMBL.2018010101 
Player-Koro, C., Bergviken Rensfeldt, A., \& Selwyn, N. (2018). Selling tech to teachers: Education trade shows as policy events. Journal of Education Policy, 33(5), 682-703. https://doi.org/10.1080/02680939.2017.1380232.

Poirier, M., Law, J. M., \& Veispak, A. (2019). A spotlight on lack of evidence supporting the integration of blended learning in $\mathrm{K}-12$ education: A systematic review. International Journal of Mobile and Blended Learning, 17(4), 1-14. https://doi.org/10.4018/ IJMBL.2019100101

Rapid Research Information Forum (RRIF). (2020). Learning outcomes for online versus in-class education. Australian Academy of Science. https://www.science. org.au/covid19/learning-outcomes-online-vs-inclasseducation

Ray, K. (2020). The Just in time playbook for remote learning. Techlearning.

Roddy, C., Amiet, D. L., Chung, J., Holt, C., Shaw, L., McKenzie, S., Garivaldis, F., Lodge, J. M., \& Mundy, M. E. (2017). Applying best practice online learning, teaching, and support to intensive online environments: An integrative review. Frontiers in Education, 2, 59. https:// doi.org/10.3389/feduc.2017.00059

Sammons, P., Toth, K., Sylva, K., Melhuish, E., Sirah, I., \& Taggart, B. (2015). The long-term role of the home learning environment in shaping students' academic attainment in secondary school, Journal of Children's Services, 10(3), 189-201.

Schleicher, A. (2018). Teachers' well-being, confidence and efficacy. In Valuing our Teachers and Raising their Status: How Communities Can Help. OECD Publishing.

Schlosser, L., \& Simonson, M. (2019). Distance education: Definition and glossary of terms (4th Ed.). Information Age.

Selwyn, N., Macgilchrist, F., \& Williamson, B. (2020, June). Digital education after COVID-19. TECHLASH, 1. http://der.monash.edu.au//nm/wp-content/ uploads/2020/06/TECHLASH-01-COVID-education.pdf

Shlonsky, A., Mathews, B., Arney, F., Stanley, F., Bromfield, L., O'Donnell, M., Pilkington, R., \& Marriott, R. (2020, April 8). What governments can do about the increase in family violence due to coronavirus. The Conversation. http://theconversation.com/what-governments-cando-about-the-increase-in-family-violence-due-tocoronavirus- 135674

Sikora, J, Evans M.D.R., Kelley J., (2019). Scholarly culture: How books in adolescence enhance adult literacy, numeracy and technology skills in 31 societies, Social Science Research, 77, 1-15. https://doi.org/10.1016/j. ssresearch.2018.10.003.
Smith, L., \& Riley, D. (2012). School leadership in times of crisis. School Leadership and Management, 32(1), 57-7.

Sonnemann, J., \& Goss, P. (2020, June). COVID catch-up: Helping disadvantaged students close the equity gap. Grattan Institute. https://grattan.edu.au/wp-content/ uploads/2020/06/COVID-Catch-up-Grattan-SchoolEducation-Report.pdf

South Australia Department for Education. (2020). Our Learning SA. Continued learning between home and school. https://www.education.sa.gov.au/our-learning-sa

Stern, A. M., Cetron, M. S., \& Markel, H. (2009). Closing the schools: Lessons from the 1918-19 U.S. influenza pandemic: Health Affairs, 28(Supplement 1), w1066w1078. https://doi.org/10.1377/hlthaff.28.6.w1066

Teo, S., \& Griffiths, G. (2020). Child protection in the time of COVID-19. Journal of Paediatrics and Child Health, 56(6), 838-840. https://doi.org/10.1111/jpc.14916

Thalheimer, W. (2017). Does eLearning work? What the scientific research says! Work-Learning Research. https://www.worklearning.com/wp-content/ uploads/2017/10/Does-eLearning-Work-Full-ResearchReport-FINAL2.pdf

Thomas, J. (2017, August 2). Lack of internet affordability may worsen Australia's digital divide: new report. The Conversation. https://theconversation.com/lack-ofinternet-affordability-may-worsen-australias-digitaldivide-new-report-81823

Thomas, J., Barraket, J., Wilson, C. K., Rennie, E., Ewing, S., \& MacDonald, T. (2019). Measuring Australia's Digital Divide: The Australian Digital Inclusion Index 2019, RMIT University and Swinburne University of Technology, Melbourne, for Telstra. https://doi. org/10.25916/5d6478f373869

Thomson, S. (2020, April 20). What PISA tells us about our preparedness for remote learning. Teacher. https:// www.teachermagazine.com.au/columnists/suethomson/what-pisa-tells-us-about-our-preparednessfor-remote-learning

UNESCO. (2015). Sustainable Development Goal 4 (SDG 4). https://sdg4education2030.org/the-goal

United Nations. (1948). Universal Declaration of Human Rights. https://www.ohchr.org/EN/UDHR/Documents/ UDHR_Translations/eng.pdf

Virtual School Victoria (2018). Pedagogical Model for Online Learning. https://www.vsv.vic.edu.au/wp-content/ uploads/2019/12/2019-Virtual-School-VictoriaPedagogical-Model.pdf 
Watkins, D., \& Hattie, J. (2006). Individual and contextual differences in the approaches to learning of Australian secondary school students. Educational Psychology, 10(4), 333-342. https://doi. org/10.1080/0144341900100404

World Bank. (2020, March 16). Rapid response briefing note: Remote learning and COVID-19 Outbreak. http://documents 1.worldbank.org/curated/ en/266811584657843186/pdf/Rapid-ResponseBriefing-Note-Remote-Learning-and-COVID-19Outbreak.pdf

Ziebell, N., Acquaro, D., Pearn, C., \& Seah, W. T. (2020). Australian Education Survey examining the impact of COVID-19. Report summary. Melbourne Graduate School of Education. https://education.unimelb.edu.au/_data/ assets/pdf_file/0008/3413996/Australian-EducationSurvey.pdf

Zubrick, S. R., Silburn, S. R., \& Prior, M. (2005). Resources and contexts for child development: Implications for children and society. In: Richardson, S. \& Prior, M. (Eds.). No time to lose: The wellbeing of Australia's children. Melbourne University Press. 


\section{APPENDIX A PEDAGOGICAL MODELS FOR REMOTE LEARNING}

\section{Mobile learning framework}

A mobile learning approach - one that makes use of mobile devices - is an area ripe for application and research in the context of remote learning (Ismail et al., 2013; Kearney et al., 2019). Mobile devices provide a rich set of communication, documentation, and learning functionality through cameras, microphones and apps, and when incorporated creatively can provide students with authentic learning experiences, and an enhanced sense of agency.

"A mobile pedagogy is a pedagogy which employs the characteristics and affordances of mobile devices to enhance learning" (Burden et al., 2019, p.159). Table 1 shows a framework designed to describe mobile learning from a pedagogical perspective (cited in Kearney et al., 2019).

\section{Table 1. iPAC mobile learning framework}

\section{Principle constructs Sub constructs}

Personalisation

Authenticity

Collaboration

\section{Agency}

Customisation

Setting

Task

Conversation

Data sharing

In an extensive systematic literature review, and then through a best/worst survey, researchers have identified a set of 21 pedagogical principles underpinning mobile learning activities.

These range from authentic learning, real-world processes, and student agency, to digital play, gamification, and inter-generational learning (Burden et al., 2019). Principles related to authenticity were rated as most important by mobile learning experts, while principles related to personalisation and customisation were rated as most important by practising teachers (Burden et al., 2019, p. 661).

The 21 principles underpinning innovative mobile learning activities are as follows:

1. Seamless learning - Activity occurs across a variety of physical and/or virtual settings

2. Digital play - Activity involves explorations without an explicit curriculum goal

3. Student agency - Students have choice of how to do activity

4. Student autonomy - Students determine the activity

5. Gamification - Applies elements of games such as competitions, random events, scoring

6. Customisation - Learning pathways are adapted to individual input

7. Authentic environment - Activity occurs in situ

8. Simulation - Conducting realistic virtual task

9. Context-awareness - Activity adapts to environmental stimuli, for example new vocabulary is determined by external items 
10. Data sharing- Learners share digital artefacts with peers

11. Artefact construction - Learners make digital objects e.g., video, music, game

12. Co-construction - Learners use collaborative authoring tools

13. Reflection - Learners reflect in multimodal ways e.g., with vlogs, colours, sound

14. Real-world processes - Learners engage in activities similar to those done by practitioners e.g. testing aero-dynamics of object with app

15. Real-world tools - Activity uses app as tool e.g., to compose music or paint a picture

16. Role-play - Learners assemble tools and methods and enact roles e.g., citizen journalist

17. Peer review - Learners review each other's contributions e.g., via blogs

18. Co-design for mobile learning - Students and teachers 'mobilise activities' i.e., transform them into ones with mobile features

19. Intergenerational learning - Learners across different generations work together e.g. capturing an oral history

20. Bridging - Learners work across formal and informal contexts

21. Community-based - Learners conduct a community activity or project (Burden et al., 2019, p. 661).

\section{Online learning framework}

Virtual School Victoria developed its Pedagogical Model for Online Learning (2018) from a combination of evidence-informed literature, and long-term experience of remote teaching (see Table 2). It is noteworthy that the pedagogical principles in this model are appropriate for any mode of learning and teaching.

Table 2. Pedagogical Model for Online Learning (Virtual School Victoria, 2018).

\begin{tabular}{|c|c|}
\hline Domain & Elaboration \\
\hline Relationship development & $\begin{array}{l}\text { Establish and maintain a safe and positive learning environment (including online) } \\
\text { in which students feel confident to engage in learning and to interact with their } \\
\text { teachers and peers. }\end{array}$ \\
\hline Activating strategies & $\begin{array}{l}\text { Establish prior knowledge, employ 'getting knowledge ready' strategies, make } \\
\text { connections with students' learning goals and inspire them about the learning they } \\
\text { are about to undertake. }\end{array}$ \\
\hline Information exchange & $\begin{array}{l}\text { Outline learning intentions and key knowledge and skills (VCE) along with information } \\
\text { about assessment. Explicit instruction of new skills and knowledge where required. } \\
\text { Contributions from students about the topic (expanding on the establishment of } \\
\text { prior knowledge). }\end{array}$ \\
\hline Knowledge construction & $\begin{array}{l}\text { Develop and facilitate a range of activities to enable students to interact with the learning, } \\
\text { negotiate new meanings and establish new understandings. (May include collaboration } \\
\text { with peers.) }\end{array}$ \\
\hline Development & $\begin{array}{l}\text { Develop and facilitate a range of activities which consolidate the skills and knowledge } \\
\text { students have recently learned and which encourage deeper understanding of the topic } \\
\text { or skill. (May include collaboration with peers.) }\end{array}$ \\
\hline Assessment & $\begin{array}{l}\text { Develop and facilitate activities which will allow students to demonstrate their learning } \\
\text { and inform the next step in learning. (May include peer assessment.) }\end{array}$ \\
\hline Reflection & Develop and facilitate activities which guide students and teachers to reflect. \\
\hline
\end{tabular}




\section{Online engagement matrix}

Erturk and Ekundayo's (2020) matrix was developed in the Higher Education sector in New Zealand and is relevant to the Australian school context. The levels of online engagement in Table 3 show how remote teaching can catapult many teachers from Level 1 of using a learning management system for document and content provision, directly to Level 4, delivering live class sessions and meetings.

Table 3. Levels of online engagement (Erturk \& Ekundayo, 2020)

\section{Level Online engagement criteria}

Level 1 Document and content provision

Level 2

Provision of grades and feedback to students

Level 3

Evaluated activities done online, other than report submissions

Level 4 Recorded and/or live class sessions and meetings 
